\title{
Juridical Review on Safeguards in Connection with Legal Protection of the Industry in the State Based on WTO and Regulation Provisions in Indonesia
}

\author{
Rahayu Hartini \\ Faculty of Law of Muhammadiyah Malang University, Jl. Raya Tlogomas Number 246, Malang, Indonesia
}

\begin{abstract}
Safeguard is one of the legal instruments to protect domestic industries from the increase in imported goods that occur in normal trade but endanger domestic industries. To avoid this, the WTO and the Government of Indonesia issued protection regulations. The purpose of this study is to find out 1). Protection of domestic industrial law against protection in WTO rules and regulations in Indonesia. 2). Adjustment of a substance in Indonesia to protect the provisions. This legal research is normative juridical using the Law approach, analyzed in analytical content. Research results: 1). There are still some weaknesses in the protection rules in Indonesia because there are no specific rules on protection because they are still regulated in the Customs Law, while each WTO rule governed in each article is different, there is no absolute and relative explanation in terms of the imposition of safeguards.

2). in implementing safeguards there are still differences found in the form of safeguard provisions in WTO rules and regulations in Indonesia.
\end{abstract}

Keywords: Safeguard, Regulation, Legal Protection.

DOI: 10.7176/JLPG/92-02

Publication date: December $31^{\text {st }} 2019$

\section{INTRODUCTION}

Progress in the economy has experienced very rapid development lately. This is marked by the growing development of business activities, such as export-import activities, investment, service trade, licensing and franchising or other activities, such as banking, insurance, taxation, and so on (Muhammad Sood, 2012, p vii).

International trade relations, known as international trade, have experienced rapid development over time. The dynamics of international trade are followed by various complex problems as a consequence of a reasonable trade relationship that occurs in the business world. The distinctive feature of international trade is the

Existence of trade relations that are carried out across national borders carried out by business actors by following a specific and specific system. International trade is trade carried out by residents of a country with residents of other countries on the basis of mutual agreement. The residents in question can be between individuals and individuals, between individuals and the government of a country or the government of a country and other governments. In international trade, the existence of a system is a patron that forms and directs trade activities in the desired direction (Christhophorus Barutu, 2007 and Journal Hukum Gloris Juris, Volume 7. No.1, 1 Januari 2007).

In 1995, Indonesia officially became a member of the WTO and ratified all WTO agreements. Indonesia entered into the WTO through Law No. 7 of 1994 concerning Ratification of the Agreement Establishing the World Trade Organization which states that Indonesia ratified the approval of the establishment of world trade organizations. Many countries continue to strive to grow their economy. The industrial and trade sectors are one of the important sectors for economic growth. The importance of the role of the sector makes these sectors one sector that is highly considered and protected by the state.

For Indonesia, this open international market condition offers great opportunities for domestic products to be exported, but in accordance with the principle of causality Indonesia is also required to open up the domestic market for imported products to enter and circulate. The demand to open the domestic market for imported products can certainly bring intense competition from imported products, especially if the number of imported products floods the domestic market. There is a problem for domestic products if the number of imported products exceeds the number of domestic products in the domestic market. This can lead to the formation of an unfair business competition (Sylviana Kusuma Lestari, 2010, page 3).

If these conditions occur, Indonesia as a member of the WTO can implement legal measures in the form of security measures or safeguards. Safeguards or trade security measures are one of the legal instruments to protect domestic industries against the increase in imported goods that occur in normal trade but harm domestic industries. The conditions for implementing safeguard measures in article 2 of the Agreement on Safeguard

Include: 1. Members may request security measures for a product, if the product is imported into the territory in such an amount, threatening domestic similar products, causing serious harm to the domestic industry producing similar products or direct products. 2. Safeguard measures will be applied to imported products 
regardless of source. WTO data shows that Indonesia is the second largest country that actively wears safeguard measures. This can be proven since Indonesia joined the WTO from the period 01/01/1995 to 31/12/2015.

In Indonesia, the institution authorized to conduct such investigations is the Indonesian Trade Security Committee (KPPI) which was established in 2003 through the Minister of Industry and Trade Decree No. 84/MPP/ Kep/2/2003 dated February 17, 2003. This decree is a follow-up to Keppres No. 84 of 2002 dated 16 December 2002 concerning Measures to Safeguard Domestic Industries from the Impact of Import Surges.

The Indonesian Trade Safeguard Committee (KPPI) is a committee tasked with carrying out investigations in the framework of Safeguard Measures for Safeguard Requests for domestic producers who suffer serious losses and / or are threatened with serious losses, as a result of soaring imports of similar goods or goods which directly competes with domestic producer goods. KPPI has the task of handling problems related to efforts to recover serious losses or prevent the threat of serious losses suffered by the domestic industry as a result of a surge in the number of imported goods (KPPI. Profile in http://kppi.kemendag.go.id., accessed at 30 November 2016).

In addition to the World Trade Organization (WTO) which regulates trade security measures in the Agreement on Safeguard, the WTO also regulates it in Article XIX of the General Agreement on Tariffs and Trade. Some national regulations governing safeguards are Law No. 7 of 1994 concerning Ratification of the Agreement Establishing the World Trade Organization; UU no. 17 of 2006 concerning Amendments to Law No.10 of 1995 concerning Customs; Government Regulation No. 34 of 2011 concerning Antidumping Actions, Reward Actions, and Trade Security Measures and Decree of the Minister of Industry and Trade of the Republic of Indonesia No. 85/MPP/Kep/2003 concerning Procedures and Requirements for Inquiry for Investigation of the Safeguard of Domestic Industries from the Impact of Import Surges.

\section{RESEARCH OBJECTIVES}

Based on the description above, several problems arise. The objectivities of the study in this study are:

1) How about safeguards against the protection of domestic industrial law according to WTO Provisions and Regulations in Indonesia?

2).is safeguards in Indonesia in accordance with the safeguard provisions stipulated by the WTO?

\section{METHOD}

This research is juridical normative by using a statue approach, and a conceptual approach. This research is normative juridical with a literature approach that is by studying journals, books, legislation and other documents related to this research. This approach views the law as identical with written norms created and promulgated by authorized institutions or officials. In this study there are 3 legal materials: primary, secondary and tertiary. Primary legal materials which are provisions relating to Safeguards based on WTO regulations and national regulations consisting of: a. General Agreement on Tariffs and Trade (GATT) 1947; agreement on Safeguard: c. Law No. 7 of 1994 concerning Ratification of the Agreement Establishing The World Trade Organization d. Law No. 17 of 2006 concerning Amendments to Law No. 10 of 1995 concerning Customs; Government Regulation No. 34 of 2011 concerning Antidumping Actions, Reward Actions, and Trade Safeguard Measures; Secondary legal material that is all publications about law that are not official documents (books, dictionaries, journals, comments on court decisions).Tertiary legal materials namely: a large Indonesian dictionary, Law dictionary, encyclopedia, and others. Legal Material Collection Techniques with the model of library research (Jhony Ibrahim, 2006). The technique of analyzing legal material is carried out in a descriptive qualitative manner, namely the selection of theories, principles, norms, doctrines and articles in the law. Legal materials obtained are then subjected to discussion, examination and grouping into certain parts to be processed into information data (Jimly Asshiddiqie, 1997).

\section{RESULT AND DISCUSSION}

\subsection{Protection of Domestic Industrial Laws through Safeguard Measures in WTO Provisions and} Regulations in Indonesia

It was realized that it was not easy to determine the WTO agreement in accordance with the provisions applied so that there might be deviations in the liberalization process that urged the position of the domestic industry, so a safety valve was needed so that mutually beneficial international trade activities could be realized. Since the entry into force of the 1947 General Agreement on Tariffs and Trade (GATT), the safety valve scheme has always been provided, one of which is safeguard action (Christophorus Barutu, 2007, page 101).

In addition to Article XIX GATT 1947, it will be retained without being changed in the 1994 GATT. In its development, the provisions regarding safeguard are rewritten in a formulation that is somewhat different from what is stated in the Agreement on Safeguard or Agreement on Safeguard (Safeguard Agreement) which is one part of the WTO agreement (Christophorus Barutu, 2007, page 105).

In the 1994 General Agreement on Tariff and Trade (GATT), the safeguard action was intended to avoid a 
situation where WTO members faced a dilemma between letting the domestic market which was very disturbed by imported goods and withdrawing from the agreement. If the second choice is chosen by many countries, it means that the agreement will be ineffective or reduce the level of liberalization process. That is why GATT 1947 has

Special requirements in emergency actions stipulated in Article XIX GATT 1947 regarding Emergency Actions on Imports of Particular Products. It stipulates the conditions under how safeguards can be implemented (KPPI. Perlindungan Industri Dalam Negeri Melalui Kesepakatan Safeguard World Trade Organization, brochure, page 2), especially Article 1 (a) concerning unforeseen developments.

Based on Article XIX 1.a the GATT above explained that the word "if" is a condition in which the meaning in the situation referred to below is the condition under which safeguard actions can be carried out. The said safeguard action can be carried out if there are elements of unforeseen developments, there is an obligation of the parties making an agreement which includes concessions on tariffs which consequently the number of imported goods entering the region increases rapidly causing threat of serious injury (threaten serious injury) of similar products so that countries that make the agreement are given the authority to take preventative measures against more severe losses that will be experienced by domestic industries. Preventive and corrective actions can take the form of delaying the concession, withdrawing or changing the concession.

In Article XIX GATT, a country is allowed to withdraw or modify agreed concessions, impose import restrictions for a temporary period if it can be proven that an increase in certain imported products results in significant losses for domestic producers, and continues to impose import restrictions for a period of time needed to overcome the loss suffered.

The application of safeguards regulated in GATT 1994, namely Article XIX only consists of 5 (five) paragraphs which do not formulate in details procedural and substance for implementing safeguards. This causes a lot of misperceptions and confusion in interpreting the safeguard regulations. Recognizing this problem and because of the many criticisms that justify the importance of carrying out an import restriction, negotiators in the Uruguay Round agreed to make a clearer and more detailed safeguard regulation through SA.

In the Agreement on Safeguard (Safeguard Agreement), in its development, the provisions regarding safeguard were rewritten in a formulation that was somewhat different from what was stated in the Agreement on Safeguard or Agreement on Safeguard (Safeguard Agreement) which was one part of the WTO agreement. Article

2.1 Agreement on Safeguard regarding the following conditions or conditions :1).A Member may apply a safeguard measure to a product only if that Member has determined, pursuant to the provisions set out below, that such product is being imported into its territory in such increased quantities, absolute or relative to domestic production, and under such conditions as to cause or threaten to cause serious injury to the domestic industry that produces like or directly competitive products.2) Safeguard measures shall be applied to a product being imported irrespective of its source.

The above explains the safeguard conditions that in identifying an increase in imports are imported goods entering the customs territory of a country increasing in absolute and relative quantities compared to domestic production and causing serious losses or the threat of serious harm to industries that produce similar or in directly rivaled by imported goods (KPPI,2005, page 5).

There is a difference regarding the identification of increased imports between Article XIX GATT 1994 and Article 2.1 Agreement on Safeguard where in Article 2.1 the Agreement on Safeguard identification of imports is further clarified by the inclusion of an element of distinction between absolute and relative increase, which is not mentioned in Article XIX GATT 1994.

Member States must take a number of special procedures called consultations before taking any safeguard measures. After conducting new consultations the new Member State is possible if it finally decides to take safeguard action.

In Law No. 17 of 2006 concerning Amendments to Law No. 10 of 1995 concerning Customs, Basically customs that are regulated in the Customs Law in accordance with the provisions of Article 1 Number 1 are all matters relating to the supervision of the traffic of goods entering or leaving customs areas as well as the collection of import duties and export duties.

Law Number 10 of 1995 concerning Customs which originally only regulates the problem of AntiDumping Import Duty and Import Duty (Subsidies), then Law Number 17 of 2006 concerning amendments to Law number 10 of 1995 concerning customs, extends the action safeguarding trade by incorporating two new provisions, namely Safeguard Measures Import Duty and Retaliation Import Duty in addition to Anti-Dumping Import Duty and Import Duty (Christophorus Barutu, page140).

In article $23 \mathrm{~A}$ it is said that:

Import duties on security measures may be imposed on imported goods in the event that there is a surge in imported goods both in absolute or relative terms to similar domestic production goods or goods that are directly competitive, and the surge in imported goods: 
a. causing serious losses to domestic industries producing similar goods with said goods and/or goods

That are directly competitive; or

b. threaten serious damage to domestic industries that produce similar goods and/or goods that are directly competitive.

In my opinion, Indonesia, which has ratified Law No. 7 of 1994 in protecting the domestic industry from safeguards, has not been able to provide optimal preventive protection measures. This can be proven by the absence of regulations concerning safeguards that are regulated in more specific laws. Safeguards in Law Number 17 of 2006 concerning amendments to Law number 10 of 1995 concerning customs are only inserted. Whereas both WTO regulations are regulated in different Articles, safeguards are regulated in Article XIX GATT while Customs are regulated in Article VII GATT.

In Government Regulation No. 34 of 2011 concerning Antidumping Actions, Reward Actions, and Trade Safeguard Measures, it can be said that as a consequence of the ratification of the Agreement Establishing the World Trade Organization, particularly those relating to the Agreement on Safeguard, the national legal products concerning security measures make structural legal adjustments . In Government Regulation No. 34 of 2011 specifically regulates safeguard actions both in terms of their understanding and procedures.

Safeguard Measures for Trade (TPP)/Safeguard in this regulation regulated in article 1 number 3 are actions taken by the government to recover Serious Losses or prevent the Threat of Serious Losses suffered by the Domestic Industry as a result of a surge in the number of imported goods both in absolute and relative terms to Similar Goods or Goods That Are Directly Competing.

Deficiencies in Government Regulation No. 34 does not explain who are the parties interested in this government regulation. In addition, as a result of the surge in the amount of imported goods both in absolute and relative terms, the explanations regarding absolute and relative are also not explained. so with the lack of explanation this can lead to uncertainty and there are different interpretations for producers in reporting this trade security measures.

An example is the case of ceramics Tableware (Tableware Ceramics) which in early January 2006, Indonesia imposed safeguard measures for ceramics Tableware products. Safeguard imposition is imposed by Minister of Finance Regulation Number 01 / PMK.010 / 2006 concerning Imposition of Import Duty on Safeguard Measures for Import of Ceramic Tableware Products, which was established on January 4, 2006 (KPPI, Year II, 2006, page 5).

\subsection{Safeguard Provisions in Indonesia Judging from the WTO Safeguard Provisions}

In principle, open international trade requires uniformity of rules that apply at the international level with

Rules made at the national level. Uniformity of these rules is commonly referred to as a harmony between international rules and national rules. In the harmonization of this law, the most important thing is the meeting point of fundamental principles between the two, so that conflict of law is avoided (Abdurrahman Alfaqiih, 2012, Jurnal Media Hukum. Vol. 19 No. 1 Juni 2012, page 32).

Inconsistencies in the substance of the regulation and its application will have an impact on claims through the WTO Dispute Settlement Body. As an illustration, in the case of Argentina-footwear, (Argentina- Safeguard Measures on Imports of Footwear) (Argentina-Footwear), Panel Report, WT/DS121/R, 25 June 1999; Appellate Body Report, WT/DS121/AB/R: 1999) The European Union and several countries acting as third parties

Such as Brazil, Indonesia, Paraguay, Uruguay and the United States are suing Argentina at the WTO. The lawsuit is based on the actions of Argentina which imposes temporary and permanent safeguard measures on footwear products from the claimant countries. Footwear products from Indonesia and other claimant countries are subject to an import duty of US \$ 12.00 per unit with an average unit value between US \$ 11.00 and US \$ 19.00 , so ad valorem or tariff calculated as a percentage of import value exceeds $70 \%$. According to Indonesia, the Argentine National Foreign Trade Commission (ANFTC) cannot prove that the domestic industry suffered serious losses and failed to show a causal relationship between increased imports and serious losses. In determining a serious loss or threat of a serious loss, ANFTC does not show "detailed case analysis" or does not test "relevant factors". The Panel concluded that the imposition of safeguards remained based on investigations and the determination of Argentina not consistent with articles 2 and 4 of the SA.

Inconsistencies in the implementation of WTO provisions can also be seen in the case of the US- Definitive Safeguard (United States-Definitive Safeguard Measures on Imports of Certain Steel Products, Panel Reports (WT/DS248/R; WT/DS249/R; WT/DS251/R; WT/DS252/R; WT/DS253/R; WT/DS258/R; WT/DS259

/R) On March 5, 2002, the United States issued the proclamation N. 7529 entitled "to enjoy positive adjustments to competition from imports of imports of imports of imports of imports of certain steel product. "Based on this proclamation, the United States imposed a permanent safeguard on March 20, 2002 amounting to 8 to $30 \%$ of imports of certain steel products originating from plaintiff countries, including China. Inconsistent with WTO safeguard provisions, the US was declared defeated two examples of the cases above provide lessons that the substance of safeguard arrangements made by Indonesia and their application must be consistent with 
the WTO's call (Abdurrahman Alfaqiih, 2012, page 29).

A question is whether the safeguard provisions made by the Indonesian government are in accordance with the provisions that apply in the international sphere, then the principles that are fundamental to the GATT and national legislation need to be compared. These fundamental principles are examined in two categories, namely the conditions for the imposition of safeguards and the forms of safeguards that can be imposed.

The rules regarding safeguards in Indonesia are regulated more fully in Government Regulation No. 34 of 2011 concerning Antidumping Actions, Rewards Actions, and Trade Safeguard Measures, while at the international level, safeguard provisions contained in GATT are further elaborated in the Agreement on Safeguard.

First, the conditions for the imposition of safeguards. In the government regulation, the safeguard requirements can be found in the safeguard definition, which is the action taken by the government to recover Serious Losses or prevent the Threat of Serious Losses suffered by the Domestic Industry as a result of a surge in the number of imported goods both in absolute and relative terms of similar Goods or Goods that directly compete.

The purpose of Serious Losses or preventing the Serious Losses Threat in article Article 1 number 15

Serious Losses is a significant overall loss suffered by the Domestic Industry, while Article 1 number 16 Threats for Serious Losses are Serious Losses that will clearly occur in the near future to the Industry In the country where the determination is based on facts, not based on allegations, allegations, or estimates.

Regarding similar goods and directly competing goods, it has been explained in Article 1 number 10 that said Similar Products are domestic goods that are identical or equal in all respects to imported goods or goods that have characteristics resembling imported goods and Article 1 number 11 mentions Goods which are Directly

Competing means domestic goods which in use can replace the goods being investigated.

In determining such loss or threat, it is explained in article 1 number 18 Domestic Industry in the event that the Security Measures are producers as a whole of Similar Goods or Directly Competing Goods operating within the territory of Indonesia or whose production cumulatively constitutes a large proportion of the overall production of goods referred to.

Provisions regarding the conditions for the imposition of safeguard are in line with the provisions contained in the Agreement on Safeguard. It can be said that Indonesia has adjusted its substance to safeguards in the WTO regarding the conditions for the imposition of safeguards because there is no difference between the conditions for the imposition of safeguards. There should be a harmony between international rules and national rules so that there is no conflict of law.

Second, the form of safeguards in Indonesian regulations can be found in article 70 paragraph 2 PP Number 34 of 2011 in which safeguards can be imposed in the form of import duty or quota.

The purpose of the import duty of security measures themselves in article 1 number 25 PP Number 34 Of 2011: "Import duties on security measures are state levies to recover Serious Losses or prevent the Threat of Serious Losses suffered by the Domestic Industry as a result of a surge in the number of imported goods against Similar Goods or Goods that are directly Competing with the aim that the Domestic Industry is experiencing Serious Losses or The Threat of Serious Losses can make the necessary adjustments.

While the definition of quota is explained in article 1 paragraph 12 :

"Quotas are restrictions on the amount of goods by the government that can be imported."

If the safeguard chosen is an import duty, then the Minister of Finance will determine it, while the safeguard is a quota determined by the Minister of Industry and Trade. If the duty imposed is the import duty of security measures, the amount of the import duty of security measures is the highest as the amount needed to recover Serious Losses or prevent the Threat of Serious Losses to Domestic Industry. Whereas the specified quota must not be less than the average number of imports in at least the last 3 (three) years, unless there is a clear reason that a lower quota is needed to recover Serious Losses or prevent the Threat of Serious Losses to the Domestic Industry.

In the provisions of Safeguard on Agreement described in article 12 paragraph 5, the translation of which is as follows:

The results of the consultations mentioned in this article, as well as the results of the midterm review referred to in paragraph 4 of article 7, any form of compensation referred to in paragraph 1 of article 8 and the proposed postponement of the concession as well as other obligations referred to in paragraph 2 Article 8 must be immediately notified to the Council for Trade in Goods by the Member States concerned.

So it can be concluded after the results of the consultation, member countries can then take action on the form of loss they face. In the explanation of Bhagirath Lal Das, after conducting a new consultation a new Member State is possible if it finally decides to take safeguard action. These safeguard actions can be taken in the form of (Bhagirath Lal Das, 1999, page 79) : 1). Imposition of tariffs, for example in the case of increasing import obligations beyond the limit, charging additional costs or additional taxes, substituting taxes on goods, or introducing a quota tariff, that is, quotas for imports at a lower rate than charging at a higher rate for imports 
above the quota; 2).Non-tariff enforcement, for example the determination of global quotas for imports introduction of facilities in licensing, import authority, and other similar actions to control imports.

In terms of time of entry into force, PP No. 34 of 2011 divides safeguards into temporary and permanent safeguards. Provisional safeguards are regulated in article 80 , article 81 , article 82 , article 83 in which temporary safeguards can be applied in the case of recovery of domestic industry losses difficult due to delays in the imposition of Security Measures, then during the investigation period the KPPI may recommend to the Minister to impose temporary security measures. The duration of the temporary safeguard is a maximum of 200 (two Hundred) days from the date of enactment.

As for safeguards, they can only be imposed after it has been proven that serious losses or threats of serious losses are indeed caused by a surge in imports. The period of permanent safeguard is a maximum of 4 years but can be extended for a maximum of 4 years and can be extended again for a maximum of 2 years.

Similar to the provisions in PP No. 34 of 2011, in the provisions of Safeguard on Agreement there are temporary safeguards and permanent safeguards.

Temporary safeguards are carried out if there is preliminary evidence of an increase in imports resulting in serious losses or threat of serious harm to the domestic industry, temporary safeguard measures can be imposed as stipulated in Article 6 of the Agreement on Safeguard, temporary safeguard measures are needed if the Condition of the domestic industry is in "critical condition ". That is if no immediate action is taken, it will create conditions that are increasingly difficult to do repairs and recovery (KPPI, Fair Trade, No3 Tahun II Maret 2006, page 4).

Article 6 above implies that this temporary safeguard action can only be imposed in the form of increased

Import duties, and the imposition of temporary import duties is valid for a maximum of 200 days from the imposition and cannot be extended. The imposition of provisional safeguards must meet the requirements as regulated in Article 2-Article 7 and Article 12 of the Agreement on Safeguards. If in the investigation there is no evidence of an increase in imports with serious losses or threats of serious losses, the safeguard measures are temporarily stopped and the import duties that have been collected are refunded (Christophorus Barutu, 2006, page 118-119).

Safeguards can still be determined in three forms, namely an increase in import duties, an import quota, and a combination of the two forms. If safeguard measures are determined in the form of a quota, the total quota cannot be smaller than the average import data in the last three years. In other words, for the case of the imposition of a quota that differs from the average import in the last three years, it is necessary to have evidence or justification specifically (Christophorus Barutu, 2006, page 118-119).

As confirmed in Article 5.1 Agreement on Safeguard.

Countries that take safeguard measures in the form of quotas can make the biggest exporting country's agreement on the allocation of the quota. If there is no agreement, the quota of each country is determined on the export market share of each country within a certain period. The safeguard period cannot exceed four years, including the period of imposition of temporary measures if any and safeguard actions can be extended, and the extension is regulated in Article 7.3 of the Agreement on Safeguard.

Basically, safeguard measures are not permitted to be imposed on certain items again until the time period of the previous action has been completed (at least 2 years) as stipulated in Article 7.4 of the Agreement on Safeguard. However, further on Article 7.4 of the Agreement on Safeguard explained that if the previous safeguard action ended in a period of less than 180 days, the next action could be carried out if it fulfilled two things, namely

At least one year had ended after the date on which safeguard measures were imposed on the importation of the product. And besides that safeguard measures are not imposed on the same goods more than twice in the five-year period prior to the imposition of new measures (Christophorus Barutu, 2006, page 121).

The arrangement of the safeguard form in this Government Regulation is the same as the arrangement in The Agreement on Safeguard. Even if there is a difference, it is only in the temporary safeguard form, in the Agreement on Safeguard Article 6 of the Agreement of Safeguard it is stated that it should be imposed in the form of import duty (and not quota), while in PP Number 34 of 2011 article 80 paragraph 1 it is stated only to be imposed in the form of import duty tariffs on temporary safeguards rather than as an option.

\section{CONCLUSION}

1. Legal Protection of Domestic Industry Regarding Safeguard Measures in Safeguards in Indonesia still has shortcomings:

A. Regulations regarding safeguards in Indonesia have not been maximized in providing legal protection to domestic industries because safeguards in Law Number 17 of 2006 concerning amendments to Law number

10 of 1995 concerning customs are only inserted in articles $23 \mathrm{~A}$ and $23 \mathrm{~B}$, the provisions concerning the import duty of security measures is still in one unit in customs regulation whereas in both WTO 
regulations each is regulated in a different Article, safeguards are regulated in Article XIX GATT while Customs is regulated in Article VII GATT.

B. in Government Regulation No. 34 of 2011 concerning Antidumping Measures, Rewards Actions, and Trade Safeguards Measures does not explain who are the parties that are interested in this Government Regulation. In addition, as a result of the surge in the amount of imported goods both in absolute and relative terms, the explanations regarding absolute and relative are also not explained. So with the lack of explanation this can lead to uncertainty and there are different interpretations for producers in reporting this trade security measures.

C. Protection of Domestic Industry Law Regarding Safeguard Measures in Safeguards in Indonesia can be realized through preventive legal protection provided by the Government, namely by making more adequate regulations regarding safeguards, providing socialization for business actors, and conducting an assessment of import mechanisms. While repressive legal protection is done by the government by providing import duties and quotas or both so that the domestic industry does not suffer losses due to a surge in imports.

2. In the safeguard provisions in Indonesia, seen from the WTO safeguard provisions both in terms of the imposition of safeguards and in terms of the form of safeguards in Indonesia are quite consistent in its provisions. However, there are still differences found in the form of provisional safeguard, in the Agreement on Safeguard Article 6 of the Agreement of Safeguard mentioned should be imposed in the form of import duty (and not quota), while in PP Number 34 of 2011 article 80 paragraph 1 mentioned only be imposed in the form of import duty tariffs on temporary safeguards rather than as an option. In applying a rule, there should be uniformity of rules that apply at the international level with rules made at the national level so that later it can avoid conflicts of law.

\section{REFERENCES}

Book:

Bhagirath Lal Das, 1999, the World Trade Organization, a Guide to the Framework for International Trade, Malaysia: Zed Books Ltd.

Christophorus Barutu, 2007, Provisions on Antidumping, Subsidies and Safeguards in the GATT and WTO, Bandung. Citra Aditya Bakti.

Indonesian Trade Security Committee (KPPI), 2005, Protection of Domestic Industries through the Safeguards Act of the World Trade Organization, Jakarta: Indonesian Trade Security Committee. Muhammad Sood, 2012, International Trade Law, Jakarta. Rajawali Press.

\section{Journal:}

Abdurrahman Alfaqiih, 2012, Harmonization of Regulations and Effectiveness of Safeguard Institutions in Indonesia. Batam: Journal of Legal Media. Vol. 19 No. June 1, 2012. Faculty of Law. Batam International University.

Christhophorus Barutu, 2007, History of the International Trade System (From Efforts to Forming International Trade Organizations, Existence of General Agreements on Tariffs and Trade until the Establishment of the World Trade Organization). Journal of Gloris Juris Law, Faculty of Law, Atmajaya Catholic University, Volume 7. Number 1. January 1, 2007, April, Jakarta.

Indonesian Antidumping Committee \& Indonesian Trade Security Committee, Imposition of Safeguard Actions (first part), Fair Trade. Number 3 Year II. March 2006.

Indonesian Anti-dumping Committee and Indonesian Trade Security Commission. 2006, RI Wearing Safeguard Measures for Ceramic Products, Fair Trade. No. 1 Year II. January 2006.

KPPI, Protection of Domestic Industry through the Safeguard Agreement of the World Trade Organization, Brochure.

Thesis:

Sylviana Kusuma Lestari, 2010, "Juridical Review of Legal Protection of Domestic Industries through National Regulations Associated with Safeguards Efforts in the World Trade Organization (WTO)", Thesis. Jakarta. FH UI.

Internet:

Business and Management Dictionary, Ad Valorem Rates. In http: // business dictionary. com. KPPI. Profile. In the http: //kppi.kemendag. go.id

http://kppi.kemendag.go.id.

\section{Regulations:}

Law No. 7 of 1994 concerning Ratification of the Agreement Establishing The World Trade Organization 
Law No. 10 of 1995 concerning Customs

Law No. 17 of 2006 concerning Amendments to Law No. 10 of 1995 concerning Customs;

Government Regulation No. 34 of 2011 concerning Antidumping Actions, Reward Actions, and Trade Safeguard Measure

Decree of the Minister of Industry and Trade of the Republic of Indonesia No. 85/MPP/Kep/2003 concerning Procedures and Requirements for Requests for Investigation of Safeguarding Domestic Industries from the Impact of Import Surges. 